\title{
ANALISIS PENGARUH BI RATE, KURS, INFLASI, HARGA MINYAK, DAN HARGA EMAS DUNIA TERHADAP INDEKS HARGA SAHAM GABUNGAN PERIODE 2016-2019
}

\author{
Ringga Samsurufika Anggriana \\ Universitas Negeri Surabaya \\ ringgaanggriana16080574064@mhs.unesa.ac.id \\ R.A Sista Paramita \\ Universitas Negeri Surabaya \\ sistaparamita@unesa.ac.id
}

Abstract

This research is to explain the influence of BI Rate, Exchange Rate, Inflation, Crude Oil Price, and World Gold Price toward Composite Stock Price Index (CSPI). Type of research used in causality research with a quantitative approach. The sample was based on monthly time series data from January 2016 until December 2019, using a full sampling method that consists of 48 samples. This research used a multiple linear regression method. The value coefficient of determination (R2) is 0,209, means the independent variables BI Rate, Exchange Rate, Inflation, Crude Oil Price, and World Gold Price explain the dependent variable Composite Stock Price Index (CSPI) up to 20,9\% and the remaining 70,1\% explained by the other. Simultaneous test result (F test), indicating that BI Rate, Exchange Rate, Inflation, Crude Oil Price, and World Gold Price has a significant effect on the Composite Stock Price Index (CSPI). Partial test result ( $t$-test), indicates that BI Rate, Inflation, Crude Oil Price, and World Gold Price showed an insignificant influence on CSPI, while Exchange Rate harmed CSPI. The practical implication of this research provides information to investors to find out that variables affect toward Jakarta Composite Index (JCI).

Keywords: BI rate; crude oil price; CSPI; exchange rate; world gold price.

\section{PENDAHULUAN}

Pasar modal ialah pertemuannya antara pihak yang mempunyai uang banyak dan pihak yang memerlukan dana melalui jual-beli surat berharga. Tempat berlangsungnya jual-beli surat berharga ialah bursa efek yang juga merupakan arti dari pasar modal secara fisik. Bursa efek dapat digunakan sebagai badan perantara (intermediaries). Hal tersebut menunjukkan bahwa bursa efek memiliki peran penting untuk membantu meningkatkan ekonomi (Tandelilin, 2010:26). Transaksi pembelian sekuritas juga bisa dilakukan oleh investor dari negara lain. Pasar modal di Indonesia dikelola oleh Bursa Efek Indonesia, sedangkan di beberapa negara di wilayah ASEAN juga memiliki bursa efek, misalnya Kuala Lumpur Stock Exchange (KLSE) merupakan bursa efek Malaysia, Stock Exchange of Thailand merupakan bursa efek Thailand, Philippine Stock Exchange merupakan bursa efek Filipina, Singapura dengan nama Singapore Exchange, Vietnam dengan nama Ho Chi Minh Stock Exchange (Puspitasari, Siregar, \& Andati, 2015).

Dengan adanya bursa efek dapat menunjukkan pilihan investasi yang menghasilkan profit atau tingkat pengembalian yang paling optimal kepada orang yang memiliki dana yang berlebihan atau disebut investor, sehingga bursa efek dapat digunakan untuk mendukung pengalokasian dana yang efisien (Handiani 2014). Asumsinya, investasi yang memberikan pengembalian secara optimal atau tinggi ialah sektor-sektor sangat aktif, maka uang yang didapatkan dari penanam modal bisa dipakai secara produktif oleh perusahaan (Tandelilin 2010:27). Dana yang diperoleh dari investor dapat dimanfaatkan sebagai penambahan modal kerja, mengembangkan usaha, ekspansi, dan lain sebagainya (Handiani, 2014). Bursa efek juga dapat sebagai alat masyarakat melakukan investasi di surat berharga seperti saham, obligasi, reksa dana, dan lain-lain. Oleh karena itu, masyarakat bisa meletakkan uangnya disesuaikan karakteristik laba dan risiko setiap instrumen keuangan (Sa'adah \& Suhadak, 2019). 
Ringga Samsurufika Anggriana \& R.A. Sista Paramita. Analisis Pengaruh BI Rate, Kurs, Inflasi, Harga Minyak, dan Harga Emas Dunia terhadap Indeks Harga Saham Gabungan Periode 2016-2019

Di Indonesia, penanam modal yang melakukan investasi di pasar modal bisa berinvestasi di Bursa Efek Indonesia (BEI). Indeks Harga Saham Gabungan (IHSG) ialah salah satu indeks yang dilihat penanam modal di Bursa Efek Indonesia dalam melakukan investasi (Maulinda, 2018). Hal tersebut dikarenakan indeks tersebut berisi semua saham yang terdaftar pada Bursa Efek Indonesia. Seorang investor melihat keadaan pasar apakah keadaan pasar sedang baik atau butuk melalui pergerakan perubahan indeks harga saham gabungan (idx.co.id, 2019). Dengan adanya perbedaan keadaan pasar tersebut pasti akan membutuhkan cara yang tidak sama dari investor untuk melakukan investasi. Penanam modal juga dapat mempertimbangkan beberapa indikator pada ekonomi makro, pertimbangan tersebut akan membantu dalam mengambil keputusan dalam berinvestasi yang akan dilakukan. Indikator pada ekonomi makro yang sering digunakan dalam pasar modal adalah suku bunga, kurs, inflasi (Sudarsana \& Candraningrat, 2014). Pergerakan IHSG tersebut ditunjukkan pada gambar 1

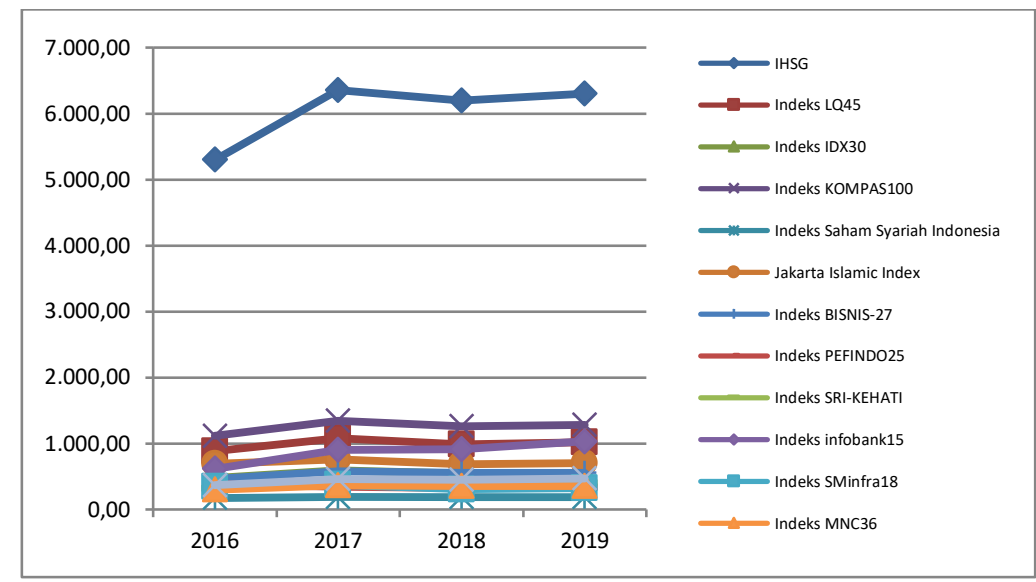

Sumber: investing.com (2019, data diolah)

\section{Gambar 1. GRAFIK PERGERAKAN 12 INDEKS YANG ADA DI INDONESIA PADA TAHUN 2016-2019.}

Gambar 1 memperlihatkan Indeks Harga Saham Gabungan (IHSG) berada di nilai tertinggi daripada indeks lainnya dikarenakan IHSG menggunakan semua komponen list di Bursa Efek Indonesia, jadi dari 11 Indeks tersebut perhitungannya ada di IHSG, sehingga melalui IHSG investor mendapatkan informasi secara relevan terkait dengan pergerakan Indeks Harga Saham Gabungan (IHSG), karena nilai dari portofolio saham tergantung pergerakan indeks-indeks.

Data harga historis yang telah diteliti menunjukkan bahwa dari tahun 2016 sampai dengan tahun 2017 IHSG cenderung naik secara signifikan. Kondisi tersebut terlihat dengan dengan naiknya IHSG yang semula pada tahun 2016 berada di posisi 5.296,7, kemudian saat tahun 2017 berada di posisi 6.355,65. Saat tahun 2018 IHSG mengalami penurunan ke posisi 6.194,50, tetapi kemudian kembali terjadi kenaikan pada tahun 2019 ke posisi 6.299,54.

Menurut Direktur Utama PT Bursa Efek Indonesia (BEI) Tito Sulistio, Bursa Efek Indonesia mampu bertahan meskipun keadaan perekonomian global tidak stabil. Bahkan beliau melaporkan pendapatan Bursa Efek Indonesia termasuk gemilang lantaran termasuk 5 tertinggi di dunia dan kedua di Asia Pasifik. Analis PT Semesta Indovest Aditya Perdana menambahkan bahwa kurs rupiah konstan atas dolar Amerika Serikat (AS) juga mendukung penguatan IHSG (Liputan6.com, 2016). Menurut Ketua Dewan Komisioner Otoritas Jasa Keuangan Muliaman Hadad, keberhasilan tax amnesty di nilai mampu melindungi penguatan IHSG serta kurs di tengah dinamika naiknya Fed Fund Rate dan tidak stabil harga minyak. Posisi tersebut meningkatkan IHSG sebesar 15,45\% dibanding tahun lalu (Tempo.com, 2016).

Pergerakan indeks pada tahun 2017 didorong sektor perbankan, pertambangan, dan barang konsumsi. Data dalam negeri menurut Aditya menunjukkan inflasi yang cukup rendah terjaga dikisaran 3\%-4\%, 
suku bunga relatif rendah, dan iklim politik terbilang bagus (Kontan.co.id, 2017). Berlandaskan dari data Bursa Efek Indonesia, IHSG -2,54\% sejak Januari hingga Desember 2018. Menurunnya indeks selama satu tahun tidak terlepas dari sebesar katalis negatif baik dari dalam negeri maupun luar negeri (Indonesia.com, 2018). Tahun 2019, IHSG hanya tumbuh 1,7\% year to date (ytd). Direktur Utama (BEI) Inarno Djajadi mengatakan, tahun ini memang tak mudah lantaran tekanan eksternal masih cukup berat. "Itu berpengaruh terhadap indeks dan yang kita lihat IHSG mengalami pengaruh terhadap external factor,". Memasuki bulan Desember, IHSG secara perlahan mulai pulih yaitu menguat 2,75\% meski ditutup melemah (Tirto.id, 2019). Penyebab penguatan IHSG bulan Desember karena masuknya dana dari investor asing (foreign). Dalam sebulan terakhir asing mencatatkan beli bersih Rp 2,95 triliun di pasar reguler (Indonesia.com, 2019).

Perubahan keadaan dalam pasar bisa dilihat dari pergerakan pada nilai indeks. Pasar yang dalam keadaan baik akan sering terjadi transaksi, hal ini ditunjukkan pada indeks harga saham yang mendapati peningkatan. Kondisi pasar yang konstan ditampilkan pada indeks harga saham yang pergerakannya konsisten. Keadaan pasar yang jelek atau lesu bisa dilihat pada menurunnya nilai indeks harga saham (Tesa, 2012). Perkembangan Indeks Harga Saham Gabungan (IHSG) terpengaruh oleh makro ekonomi di sebuah negara yang mengalami perubahan. Adapula beberapa variabel makro ekonomi yang bisa menyebabkan perubahan pada pergerakan indeks harga saham, antara lain BI Rate, kurs, serta inflasi (Rustyaningsih \& Purwohandoko, 2018).

Di Indonesia kebijakan suku bunga ditentukan oleh Bank Indonesia melalui BI rate. BI Rate merupakan suku bunga kebijakan yang menggambarkan stance kebijakan moneter yang diputuskan oleh Bank Indonesia lalu diinformasikan untuk masyarakat. Perubahan yang terjadi disuku bunga bisa memicu pergerakan di Bursa Efek Indonesia. Pada tahun 2016 acuan Suku bunga diganti dengan BI 7-Day Repo Rate yang digunakan mulai tanggal 19 Agustus 2016 (Bank Indonesia, 2019). Penelitian yang dilakukan oleh Gumilang, Hidayat, \& Endang NP (2014) dan Robiyanto (2018) menunjukkan bahwa saat suku bunga terjadi peningkatan maka harga saham akan turun dan sebaiknya.

Variabel makro ekonomi lainnya yang bisa memberikan pengaruh pada harga saham adalah kurs atau nilai tukar mata uang. Menurut Bank Indonesia (2019), kurs yaitu harga satu unit mata uang luar negeri atas mata uang dalam negeri atau dapat juga dikatakan harga mata uang dalam negeri atas mata uang luar negeri. Penelitian ini menggunakan kurs Dollar AS (USD/IDR). Berubahnya nilai tukar bisa memberikan pengaruh pada pergerakan dalam harga saham dan akan menimbulkan pengaruh dalam investasi di pasar modal. Harga barang-barang impor yang mengalami peningkatan disebabkan oleh kurs rupiah atas dollar yang terjadi depresiasi. Hal tersebut akan menaikkan biaya pembuatan yang akan dikeluarkan perusahaan, sehingga perusahaan yang memakai bahan baku impor dalam proses produksinya akan mengalami menurunnya laba. Turunnya laba perusahaan berpengaruh pada menurunnya minat para penanam modal untuk melakukan investasi pada perusahaan tersebut. Sehingga, hal tersebut bisa memengaruhi perkembangan Indeks Harga Saham Gabungan (Gumilang et al., 2014).

Inflasi merupakan faktor yang bisa memengaruhi perkembangan Indeks Harga Saham Gabungan (IHSG) (Tesa, 2012). Inflasi merupakan meningkatnya harga berkepanjangan dalam waktu tertentu. Satu barang saja yang harganya meningkat tidak bisa dikatakan inflasi, kecuali harga barang itu bisa memengaruhi harga barang yang lain (Bank Indonesia, 2019). Menurut Tandelilin (2010: 342), inflasi ialah harga produk-produk yang mengalami peningkatan secara menyeluruh.

Faktor keempat yang memengaruhi pergerakan dalam Indeks Harga Saham Gabungan (IHSG) adalah harga minyak dunia. Kenaikan harga minyak akan memicu naiknya harga barang kebutuhan lainnya (Handiani, 2014). Menurut Gumilang et al., (2014) harga minyak dunia yang terjadi peningkatan hendak memengaruhi harga pada barang-barang kebutuhan lainnya. Hal ini disebabkan karena minyak termasuk dalam kebutuhan vital (Gumilang et al., 2014). Hal ini juga dapat berpengaruh pada harga saham dan juga IHSG. 
Ringga Samsurufika Anggriana \& R.A. Sista Paramita. Analisis Pengaruh BI Rate, Kurs, Inflasi, Harga Minyak, dan Harga Emas Dunia terhadap Indeks Harga Saham Gabungan Periode 2016-2019

Dalam melakukan investasi, emas mempunyai peran penting yaitu emas digunakan sebagai alternatif untuk melakukan investasi (Utha, 2015). Menurut Chabachib \& Agung (2011), emas merupakan investasi yang bebas dari risiko. Hal tersebut disebabkan karena harga emas tidak terpengaruh oleh perubahan inflasi yang terjadi. Harga emas bisa memengaruhi pergerakan pada Indeks Harga Saham Gabungan (IHSG) yang ditunjukkan dengan sifatnya bebas risiko dengan harga yang mengalami peningkatan dari tahun ke tahun (Chabachib \& Agung, 2011).

Beberapa penelitian telah dilakukan untuk mengetahui pengaruh BI Rate, nilai tukar, inflasi, harga minyak dunia, harga emas dunia atas Indeks Harga Saham Gabungan (IHSG), di antaranya adalah penelitian Gumilang et al., (2014) menunjukkan hasil penelitian bahwa BI Rate, nilai tukar dan harga minyak dunia berpengaruh negative significant atas Indeks Harga Saham Gabungan sedangkan harga emas dunia berpengaruh positive significant atas Indeks Harga Saham Gabungan. Menurut Sartika (2017), suku bunga, nilai tukar, harga emas dunia, harga minyak dunia tidak berpengaruh significant atas Indeks Harga Sahan Gabungan. Menurut Witjaksono (2010), suku bunga, nilai tukar tidak berpengaruh significant atas Indeks Harga Saham Gabungan sedangkan harga emas dunia, harga minyak dunia berpengaruh positive sigificant atas Indeks Harga Saham Gabungan. Menurut Fatihudin \& Firmansyah (2018), nilai tukar dan inflasi berpengaruh positive atas Indeks Harga Saham Gabungan.

Penelitian ini bertujuan untuk menganalisis pengaruh BI rate, kurs, inflasi, harga minyak, dan harga emas dunia terhadap Indeks Harga Saham Gabungan.

\section{KAJIAN PUSTAKA DAN PENGEMBANGAN HIPOTESIS}

\section{Contagion Effect Theory}

Menurut Trihadmini, (2011) Contagion Effect yaitu terjadinya krisis moneter yang terjadi atas sebuah negara yang dapat menimbulkan krisis moneter ke beberapa negara. Negara-negara yang memiliki keadaan geografis yang berdampingan terutama negara-negara tersebut terletak dalam kawasan atau wilayah yang sama merupakan objek dari efek domino. Teori contagion effect ini diibaratkan apabila sebuah negara mengalami perubahan baik perubahan berskala kecil maupun berskala besar, maka dapat menyebabkan perubahan pada negara yang letaknya berada pada wilayah atau kawasan yang sama. pengaruh domino berfungsi atas negara yang sudah maju, sehingga negara negara berkembang serta negara-negara yang letaknya saling berdekatan dapat dipengaruhi oleh negara maju (Jayanti 2014).

\section{Signalling Theory}

Menurut Fahmi dan Hadi (2009:108), teori sinyal (signalling theory) merupakan teori yang menujukkan kondisi perusahaan. Konsep sinyal menjelaskan atas argumen perusahaan memberikan informasi yang akan digunakan dalam bursa efek. Menurut Krisna \& Wirawati (2013), manajemen perusahaan dan pihak-pihak yang berkepentingan (stakeholder) memiliki informasi yang berbeda atau terdapat asimetri.

\section{Indeks Harga Saham Gabungan (Y)}

Data dalam penelitian ini merupakan data hasil perubahan harga closing prise IHSG setiap bulan pada tahun bersangkutan yaitu tahun 2016 sampai 2019. Pada penelitian ini, IHSG dihitung menggunakan rumus perubahan yang dapat dilihat di rumus (1) Kusumawati \& Asandimitra (2017).

$I H S G=\frac{I H S G t-I H S G t-1}{I H S G t-1}$.

Keterangan:

IHSG : Indeks Harga Saham Gabungan

IHSG $_{\mathrm{t}}$ : Indeks Harga Saham Gabungan Periode ${ }_{\mathrm{t}}$

$\mathrm{IHSG}_{\mathrm{t}-1}$ : Indeks Harga Saham Gabungan Periode $\mathrm{t}_{\mathrm{t}-1}$ 


\section{Suku Bunga BI Rate $\left(\mathbf{X}_{1}\right)$}

Menurut Amin (2012), suku bunga ialah tingkat bunga yang telah diputuskan oleh Bank Indonesia dan menjadi acuan selaku tingkat bunga standard oleh bank pemerintah dan bank swasta. Penelitian ini perhitungannya memakai nilai BI Rate asli setiap bulannya dari tahun 2016 sampai dengan tahun 2019.

\section{$\operatorname{Kurs}\left(\mathbf{X}_{2}\right)$}

Nilai tukar (kurs) ialah suatu kurs mata uang asing atas mata uang negara lain (Amin, 2012). Menurut Handiani (2014), nilai tukar ialah perbandingan nilai mata uang suatu negara atas negara lain. Kurs rupiah pada penelitian ini menggunakan perubahan nilai kurs tengah rupiah atas dollar Amerika dari bulan Januari 2016 sampai bulan Desemeber 2019. Rumus perubahannya dapat dilihat di rumus (2) (Mahdi \& Kaluge, 2009)

Kurs Rupiah $=\frac{\text { Kurs Tengah } t-\text { Kurs Tengah } t-1}{\text { Kurs Tengah } t-1}$.

Keterangan:

Kurs tengah $_{\mathrm{t}} \quad$ : Kurs tengah periode $_{\mathrm{t}}$

Kurs tengah $\mathrm{t}_{\mathrm{t}-1} \quad$ : Kurs tengah periode $\mathrm{t}_{\mathrm{t}-1}$

\section{Inflasi $\left(\mathbf{X}_{3}\right)$}

Indeks Harga Konsumen (IHK) ialah indeks yang sering dipakai dalam menghitung inflasi. IHK ialah indikator yang menghitung harga rata-rata dari jasa dan barang yang sedang digunakan masyarakat (Jayanti, 2014). Inflasi pada penelitian ini menggunakan perubahan IHK atas setiap bulannya dari tahun 2016 sampai dengan tahun 2019. Rumus perubahannya dapat dilihat di rumus (3) (Sartika, 2017).

Inflasi $=\frac{I H K t-I H K t-1}{I H K t-1}$

Keterangan:

IHK $_{\mathrm{t}} \quad$ : Indeks Harga Konsumen Periode ${ }_{\mathrm{t}}$

$\mathrm{IHK}_{\mathrm{t}-1}$ : Indeks Harga Konsumen Periode $\mathrm{t}_{\mathrm{t}-1}$

\section{Harga Minyak Dunia $\left(\mathbf{X}_{4}\right)$}

Menurut Gumilang et al., (2014) West Intermediete (WTI) merupakan harga minyak dunia yang kerap dipakai acuan untuk perdagangan minyak, acuan tersebut yang akan digunakan dalam penelitian ini dihitung melalui perubahan yang terjadi disetiap bulannya selama tahun 2016 sampai dengan tahun 2019. Rumus perubahannya dapat dilihat di rumus (4) (Sartika, 2017).

Harga Minyak $=\frac{\text { Harga Minyak t-Harga Minyak t-1 }}{\text { Harga Minyak } t-1}$

Keterangan:

Harga Minyak $_{\mathrm{t}} \quad$ : Harga Minyak Periode ${ }_{\mathrm{t}}$

Harga Minyak $\mathrm{t}_{\mathrm{t}-1} \quad$ : Harga Minyak Periode $\mathrm{t}-1$

\section{Harga Emas Dunia $\left(\mathbf{X}_{5}\right)$}

Menurut Gumilang et al., (2014) Standar emas pasar London atau disebut dengan London Gold Fixinng dipakai untuk acuan semua negara dalam menentukan harga emas. Harga emas London yang dipakai pada penelitian ini dihitung melalui perubahan yang terjadi disetiap bulannya selama tahun 2016 sampai dengan tahun 2019. Rumus perubahannya dapat dilihat di rumus (5) (Sartika, 2017).

Harga Emas $=\frac{\text { Harga Emas } t-\text { Harga Emas } t-1}{\text { Harga Emas } t-1}$ 
Ringga Samsurufika Anggriana \& R.A. Sista Paramita. Analisis Pengaruh BI Rate, Kurs, Inflasi, Harga Minyak, dan Harga Emas Dunia terhadap Indeks Harga Saham Gabungan Periode 2016-2019

Keterangan:

Harga Emas : Harga Emas Periode $_{\mathrm{t}}$

${\text { Harga } \text { Emas }_{\mathrm{t}-1} \quad \text { : Harga Emas Periode }}_{\mathrm{t}-1}$

\section{Hubungan antar Variabel}

Suku bunga yang naik akan memengaruhi secara negatif atas pasar modal. Pada Signalling Theory menurut Jogiyanto (2000:392) dalam penelitian Maulinda (2018), menjelaskan bahwa informasi yang dipublikasikan perusahaan sebagai pengumuman akan memberikan sinyal bagi para investor untuk mengambil keputusan dalam berinvestasi. Jika pengumuman yang dipublikasikan tersebut positif, maka diharapkan pasar akan merespon positif pada waktu atau setelah pengumuman tersebut diterima oleh pasar. Jika suku bunga SBI meningkat, maka investor akan mendapatkan hasil yang lebih besar atas suku bunga deposito yang ditanamkan sehingga investor akan cenderung untuk mendepositokan modalnya dibandingkan menginvestasikan dalam saham (Sartika 2017). Penelitian yang dilakukan oleh Gumilang, Hidayat, \& Endang NP (2014), Robiyanto (2018) dan Witjaksono (2010) menunjukkan adanya pengaruh signifikan negatif yang artinya saat suku bunga mengalami kenaikan maka harga saham akan turun dan sebaiknya.

H1: BI Rate berpengaruh negatif terhadap Indeks Harga Saham Gabungan periode 2016-2019.

Menurut Darmadji (2006) dalam penelitian Sartika (2017), nilai tukar mata uang atau sering disebut kurs merupakan harga mata uang terhadap mata uang lainnya. Berdasarkan signalling theory pergerakan harga saham bergantung dari informasi yang diterima oleh investor. Informasi tersebut bisa berupa good news atau bad news. Penentuan nilai kurs mata uang suatu negara dengan mata uang negara lain ditentukan sebagaimana halnya barang yaitu oleh permintaan dan penawaran mata uang yang bersangkutan. Hukum ini juga berlaku pada kurs rupiah, jika permintaan akan rupiah lebih besar daripada penawarannya, maka kurs rupiah akan terapresiasi, demikian pula sebaliknya. Ketika mata uang rupiah terdepresiasi, maka mengakibatkan naiknya biaya bahan baku, sehingga menyebabkan kenaikan biaya produksi dan akan berpengaruh pada penurunan tingkat keuntungan perusahaan. Hal ini akan mendorong investor untuk menjual saham-saham yang dimilikinya. Apabila banyak investor yang melakukan hal tersebut, tentu akan mendorong penurunan indeks harga saham gabungan (Witjaksono 2010). Hasil riset oleh Harsono \& Wonokinasih, (2018); Husnul et al., (2017); Jayanti (2014); Lestari et al., (2016); Prawirosaputro \& Hapsari (2017) bahwa adanya pengaruh nilai tukar (kurs) menandakan bahwa semakin tinggi nilai tukar (kurs) dapat mengakibatkan penurunan terhadap indeks harga saham gabungan.

H2: Nilai tukar (Kurs) berpengaruh negatif terhadap Indeks Harga Saham Gabungan periode 20162019.

Inflasi merupakan faktor ekonomi yang dapat memberikan pengaruh pada pergerakan Indeks Harga Saham Gabungan. Menurut Bank Indonesia (2019), inflasi diartikan sebagai naiknya harga secara umum dan terus menerus dalam jangka waktu tertentu. Tandelilin (2010:342) menyatakan bahwa inflasi adalah harga produk-produk di masyarakat yang meningkat secara menyeluruh. Jadi apabila inflasi meningkat drastis maka akan memengaruhi harga sama suatu negara, karena perusahaan akan mengalami kebangkrutan atas biaya bahan baku yang sangat tinggi. Berdasarkan signalling theory pergerakan harga saham bergantung dari informasi yang diterima oleh investor. Informasi tersebut bisa berupa good news atau bad news. Inflasi dapat dikatakan sebagai informasi ganda karena inflasi dapat menyebabkan informasi bersifat good news atau bad news. Ketika suatu kondisi perekonomian sedang krisis, maka inflasi akan naik sehingga kurs rupiah terhadap dollar melemah karena biaya akan konsumsi lebih besar dari sebelumnya sehingga permintaan akan dollar semakin tinggi dan membuat melemahnya nilai tukar rupiah. Hasil riset Nofiatin (2013) dan Sudarsana \& Candraningrat (2014) menunjukkan bahwa inflasi berpengaruh negatif terhadap IHSG karena apabila inflasi meingkat, maka IHSG semakin menurun.

H3: Inflasi berpengaruh negatif terhadap Indeks Harga Saham periode 2016-2019. 
Minyak dapat memengaruhi pasar modal. Naiknya harga minyak akan memicu naiknya harga barang kebuhan lainnya. Menurut Gumilang et al., (2014) kenaikan harga minyak dunia akan menyebabkan naiknya barang-barang kebutuhan lainnya karena minyak merupakan salah satu kebutuhan vital. Hal ini juga dapat berpengaruh pada harga saham dan juga Indeks Harga Saham Gabungan. Bagi negara pengekspor minyak dan perusahaan sektor pertambangan,kenaikan harga minyak dunia dapat memberikan keuntungan karena akan menarik minat investor. Akan tetapi, bagi perusahaan di luar sektor pertambangan, hal ini akan mengakibatkan kerugian karena biaya operasional meningkat. Peningkatan dan penurunan laba berpengaruh pada harga saham perusahaan yang pada akhirnya akan mempengaruhi nilai IHSG (Handiani 2014). Sejalan dengan teori cntagion effect menjelaskan bahwa keadaan ekonomi suatu negara yang berakibat pada negara lainnya. Penelitian yang dilakukan oleh Gumilang et al., (2014) dan Rochman, (2018) memunjukkan bahwa harga minyak dunia berpengaruh signifikan negatif terhadap Indeks Harga Saham Gabungan.

H4: Harga minyak dunia berpengaruh negatif terhadap Indeks Harga Saham Gabungan periode 2016-2019.

Harga emas berdasarkan standar pasar emas London atau yang biasa disebut dengan London Gold Fixing (Gumilang et al., 2014). London Gold Fixing merupakan sistem penetapan harga emas yang dilaksanakan dua kali pada setiap hari kerja di pasar London. Emas termasuk ke dalam golongan hasil tambang yang memiliki nilai tinggi dan jumlah yang terbatas. Menurut beberapa teori dan penelitian terdahulu emas dan saham merupakan jenis barang yang bersifat substitusi. Artinya, ketika investasi saham dianggap tidak menguntungkan investor cenderung mengalihkan dananya dalam bentuk investasi emas, begitu pula sebaliknya. Disisi lain, emas juga sebagai produk andalan emiten pertambangan (Utha, 2015). Apabila investor lebih memilih untuk melakukan investasi pada emas, maka Indeks Harga Saham Gabungan akan menurun karena aksi jual investor. Sejalan dengan teori cntagion effect menjelaskan bahwa keadaan ekonomi suatu negara yang berakibat pada negara lainnya. Hasil riset Lestari et al., (2016) menujukkan bahwa harga emas yang mengalami penurunan menyebabkan naiknya IHSG di Bursa Efek Indnesia karena saat inilah investor memilih untuk melakukan investasi emas karena emas telah terbukti sebagai sarana penyimpan kekayaaan yang tahan terhadap inflasi maupun deflasi

H5: Harga emas dunia berpengaruh negatif terhadap Indeks Harga Saham Gabungan periode 20162019.

\section{METODE PENELITIAN}

Penelitian ini termasuk dalam kausalitas karena membuktikan pengaruh variabel independen atas variabel dependen. Pendekatan yang dipakai pada penelitian ini ialah pendekatan kuantitatif. Dalam penelitian ini data yang digunakan adalah data sekunder. Data tersebut berupa data indeks harga saham gabungan, suku bunga, nilai tukar (kurs), inflasi, harga minyak dunia, dan harga emas dunia. Penelitian ini mengambil populasi dari data closing price Indeks Harga Saham Gabungan (IHSG) setiap bulan di Bursa Efek Indonesia (BEI) sepanjang bulan pengamatan yaitu Januari 2016 hingga Desember 2019. Penelitian ini dalam mengambil sampel memakai metode sampel jenuh (sensus) yang dikarenakan semua populasi dipakai sampel. Sampel berjumlah 48 data (4 tahun x 12 bulan). Namun terdapat 7 data yang masuk kedalam data outlier, sehingga data tersebut harus dihilangkan, sehingga data yang digunakan berjumlah 41 .

\section{HASIL DAN PEMBAHASAN}

\section{Statistik Deskriptif}

Untuk memperlihatkan gambaran secara umum variabel terikat dan variabel bebas, digunakan uji statistik deskriptif seperti yang dapat dilihat di tabel 1. Pada variabel IHSG, nilai terendah yaitu sebesar -0,0619, nilai tertinggi sebesar 0,0678, mean sebesar 0,006971, dan nilai Std. Deviasi sebesar 0,0272906. Std. Deviasi variabel IHSG mempunyai keberagaman bervariasi dikarenakan Std. Deviasi 
Ringga Samsurufika Anggriana \& R.A. Sista Paramita. Analisis Pengaruh BI Rate, Kurs, Inflasi, Harga Minyak, dan Harga Emas Dunia terhadap Indeks Harga Saham Gabungan Periode 2016-2019

$>$ mean. Kemudian variabel suku bunga, nilai terendah yaitu sebesar 0,0425, nilai tertinggi sebesar 0,0725, mean sebesar 0,052188, dan nilai Std. Deviasi sebesar 0,0074845. Std. Deviasi variabel BI Rate tidak mempunyai keberagaman data bervariasi dikarenakan Std. Deviasi $<$ mean .

\section{Tabel 1.
STATISTIK DESKRIPTIF}

\begin{tabular}{llrrrr}
\hline Variabel & N & \multicolumn{1}{c}{ Minimum } & Maximum & \multicolumn{1}{c}{ Mean } & Std. Deviation \\
\hline Suku Bunga & 48 &, 0425 &, 0725 &, 052188 &, 0074845 \\
Kurs & 48 &,- 0752 &, 0826 &, 000419 &, 0236764 \\
Inflasi & 48 &,- 1910 &, 3047 &, 000358 &, 0998328 \\
Harga Minyak Dunia & 48 &,- 2202 &, 1977 &, 014094 &, 0852619 \\
Harga Emas Dunia & 48 &,- 0738 &, 1107 &, 008206 &, 0372532 \\
IHSG & 48 &,- 0619 &, 0678 &, 006971 &, 0272906 \\
Valid N (listwise) & 48 & & & & \\
\hline
\end{tabular}

Sumber : Hasil dari Output SPSS (2020, data diolah)

Pada variabel kurs, nilai terendah yaitu sebesar -0,0752, nilai tertinggi sebesar 0,0826, mean sebesar 0,000419, dan nilai Std. Deviasi sebesar 0,0236764. Std. Deviasi variabel kurs mempunyai keberagaman data bervariasi dikarenakan Std. Deviasi > mean. Kemudian variabel inflasi, nilai terendah yaitu sebesar $-0,1910$, nilai tertinggi sebesar 0,3047, mean sebesar 0,000358, dan nilai Std. Deviasi sebesar 0,0998328. Std. Deviasi variabel inflasi mempunyai keberagaman data bervariasi dikarenakan Std. Deviasi > mean.

Pada variabel harga minyak dunia, nilai terendah yaitu sebesar $-0,2202$, nilai tertinggi sebesar 0,1977 , mean sebesar 0,014094, dan nilai Std. Deviasi sebesar 0,0852619. Std. Deviasi variabel harga minyak dunia mempunyai keberagaman data bervariasi dikarenakan Std. Deviasi > mean. Kemudian variabel harga emas dunia, nilai terendah yaitu sebesar -0,0738, nilai tertinggi sebesar 0,1107 , mean sebesar 0,008206, dan nilai Std. Deviasi sebesar 0,0372532. Std. Deviasi variabel harga emas dunia mempunyai keberagaman data bervariasi dikarenakan Std. Deviasi > mean.

\section{Hasil Uji Asumsi Klasik}

Berdasarkan tabel 2, hasil uji normalitas dengan Kolmogorov-Smirnov (K-S) setiap variabel menunjukkan Aymp. Sig. 2-tailed lebih dari 0,05 maka data residual telah terdistribusi normal. Pada tabel 2, uji heteroskedastisitas menggunakan uji Glejer. Dari hasil SPPS diketahui nilai sgnifikansi setiap variabel lebih dari 0,05 sehingga model regresi tidak mengalami heteroskedastisitas. Tabel 2 menunjukkan hasil uji multikolinieritas, yaitu nilainya leih besar atau sama dengan nilai 0,10 . Kemudian, pada nilai VIF sudah memenuhi kriteria yaitu memberikan hasil nilai yang kurang dari 10 . Maka tidak adanya korelasi antar variabel dan model regresi tidak terdapat multikolinieritas

Kemudian hasil pengujian autokorelasi pada tabel 2 dengan Durbin-Watson, hasilnya telah ditemukan du senilai 1,7835 serta nilai dw senilai 1,786. Nilai D-W berada di antara du dan 4-du yaitu $1,7835<1,786<2,2165$ memberikan hasil bahwa tidak terdapat autokorelasi yang positif atau negatif, dan tidak terjadi autokorelasi pada penelitian ini. Hasil pengujian linieritas pada tabel 2 dengan uji lagrange multiplier dari nilai $\mathrm{R}^{2}$ yaitu 0,308 dengan $\mathrm{n}=41$, sehingga nilai $\mathrm{c}^{2}$ hitung sebesar 12,628. Kemudian besarnya nilai $\mathrm{c}^{2}$ tabel dengan taraf kepercayaan 0,05 adalah 49,81 . Nilai $\mathrm{c}^{2}$ hitung lebih kecil dari $\mathrm{c}^{2}$ tabel $(12,628<49,81)$ maka model yang tepat untuk digunakan adalah model linier. Berdasarkan tabel 3, diperoleh model persamaan (6).

$\mathrm{IHSG}=0,004+(-0,789)$ Kurs $+\mathrm{e}$

Dari kelima variabel penelitian terdapat satu variabel yang memberikan pengaruh signifikan terhadap variabel dependen yaitu variabel Kurs $\left(\mathrm{X}_{2}\right)$. Berdasarkan persamaan regresi berganda dapat dijelaskan bahwa nilai konstanta sebesar 0,004 berarti bahwa jika nilai kurs konstan, atau sama dengan nol, maka nilai IHSG adalah 0,004, sedangkan kurs yang memiliki nilai -2,264 berarti bahwa jika nilai 
kurs meningkat 1 satuan, maka nilai IHSG akan mengalami kenaikan sebesar $-2,264$. Hasil pengujian uji $F$ pada tabel 3, memberikan hasil signifikansi $F$ hitung sebesar 0,020 lebih kecil dari 0,05. Artinya variabel independen yaitu BI rate, kurs, inflasi, harga minyak dunia, dan harga emas dunia secara bersama-sama berpengaruh terhadap variabel dependen yaitu Indeks Harga Saham Gabungan (IHSG).

Tabel 2.

HASIL UJI ASUMSI KLASIK

\begin{tabular}{|c|c|c|c|c|}
\hline Uji Asumsi Klasik & Dasar Pengambilan Keputusan & \multicolumn{3}{|c|}{ Hasil Uji } \\
\hline Uji Normalitas & $>0,05$ & \multicolumn{3}{|c|}{0,052} \\
\hline \multirow{5}{*}{ Uji Heteroskedastisitas } & $>0.05$ & BI Rate & 0,082 & \\
\hline & & Kurs & 0,940 & \\
\hline & & Inflasi & 0,233 & \\
\hline & & Harga Minyak Dunia & 0,907 & \\
\hline & & Harga Emas Dunia & 0,297 & \\
\hline \multirow[t]{6}{*}{ Uji Multikolinieritas } & $\mathrm{t}>0,10$ dan $\mathrm{VIF}<10$ & & Tolerance & VIF \\
\hline & & BI Rate & 0,821 & 1,218 \\
\hline & & Kurs & 0,586 & 1,706 \\
\hline & & Inflasi & 0,758 & 1,319 \\
\hline & & Harga Minyak Dunia & 0,790 & 1,266 \\
\hline & & Harga Emas Dunia & 0,510 & 1,960 \\
\hline Uji Autokorelasi & $\mathrm{du}<\mathrm{d}<4-\mathrm{du}$ & \multicolumn{3}{|c|}{$1,7835<1,786<2,2165$} \\
\hline Uji Linieritas & $c^{2}$ hitung $<c^{2}$ tabel & 12.628 & 49,81 & \\
\hline
\end{tabular}

Sumber: Hasil dari Output SPSS (data diolah,2020)

Berdasarkan tabel 3, bahwa nilai t hitung variabel BI Rate senilai 0,057 dengan signifikansi 0,955, sehingga BI Rate tidak memengaruhi IHSG. Besarnya nilai t hitung variabel Kurs senilai -2,264 dengan signifikansi 0,030 , sehingga kurs memengaruhi IHSG. Nilai t hitung variabel inflasi senilai 1,941 dengan signifikansi 0,060, sehingga inflasi tidak memengaruhi IHSG. Nilai t hitung variabel harga minyak dunia senilai $-0,939$ dengan signifikansi 0,354 , sehingga harga minyak dunia tidak memengaruhi IHSG. Nilai t hitung variabel harga emas dunia senilai 0,736 dengan signifikansi 0,466, sehingga harga emas dunia tidak memengaruhi IHSG.

Hasil pengujian koefisien determinasi memberikan output bahwa besarnya adjusted $R^{2}$ sebesar 0,209 atau 20,9\% maka variabel independen yaitu BI Rate, kurs, inflasi, harga minyak dunia, dan harga emas dunia dalam penelitian mampu menjelaskan variabel dependen yaitu Indeks Harga Saham Gabungan (IHSG) sebesar 20,9\%, kemudian 79,1\% dijelaskan oleh variabel lain yang tidak digunakan dalam penelitian ini seperti variabel PDB Rustyaningsih \& Purwohandoko (2018), LIBOR Tesa (2012), Indeks Nikkei 225 Widodo (2018) . Nilai R koefisien korelasi sebesar 0,308, sehingga kekuatan hubungan antara variabel independen terhadap variabel dependen sebesar 30,8\%.

Tabel 3

\section{HASIL UJI HIPOTESIS}

\begin{tabular}{lcccccc}
\hline & B & Std. Error & t & Sig. & R & Adjusted R Square \\
\hline (Constant) &, 004 &, 026 &, 162 &, 872 & & \\
BI Rate &, 029 &, 503 &, 057 &, 955 & & \\
Kurs &,- 789 &, 348 & $-2,264$ &, 030 & & \\
Inflasi &,- 075 &, 039 & $-1,941$ &, 060 & & \\
Harga Minyak Dunia &,- 047 &, 050 &,- 939 &, 354 & & \\
Harga Emas Dunia &, 099 &, 134 &, 736 &, 466 & & \\
Uji Statistik F & & & & 0,020 & & \\
Uji Koefisien & & & & & 0,308 & 0,209 \\
Determinasi & & & & & & \\
\hline
\end{tabular}

Sumber : Hasil dari Output SPSS (data diolah,2020) 
Ringga Samsurufika Anggriana \& R.A. Sista Paramita. Analisis Pengaruh BI Rate, Kurs, Inflasi, Harga Minyak, dan Harga Emas Dunia terhadap Indeks Harga Saham Gabungan Periode 2016-2019

\section{Pengaruh BI Rate terhadap Indeks Harga Saham Gabungan}

Berdasarkan hasil analisis membuktikan bahwa (BI Rate) tidak mempunyai pengaruh significant atas Indeks Harga Saham Gabungan (IHSG) tahun 2016 hingga 2019. Saat suku bunga tinggi, hal ini tidak menjadikan investor serta merta mengalihkan investasinya dari bursa efek ke pasar uang. Hal tersebut dapat dijelaskan dari tipe investor yang ada di Indonesia. Tipe investor ini ialah penanam modal yang senang melaksanakan bisnis saham jangka pendek (trader spekulan), sehingga penanam modal tersebut mengarah melaksanakan profit taking dengan expectation mendapatkan capital gain yang banyak di bursa efek. Pada sisi lain, perusahaan-perusahaan emiten yang memberikan dividen yang cukup menjanjikan return bagi pemegang saham, sehingga hal ini juga menjadi stimulus bagi investor untuk berinvestasi di saham dibandingkan dalam bentuk surat berharga di pasar uang. Penelitian ini sesuai dengan Sartika (2017) dan Krisna (2013) Suku Bunga tidak berpengaruh terhadap IHSG.

Implikasi teoritis ini tidak selaras dengan Signalling Theory, bahwa BI Rate berpengaruh terhadap Indeks Harga Saham Gabungan (IHSG). Harapan dari penelitian ini dapat menjadi sumbangsih untuk hasil penelitian yang menyatakan BI Rate tidak memengaruhi IHSG. Implikasi praktis dari penelitian ini ialah investor tidak perlmenjadikan BI Rate sebagai acuan atau bahan pertimbangan dalam berinvestasi saham, karena naik dan turunnya kebijakan BI Rate tidak berpengaruh kepada Indeks Harga Saham Gabungan (IHSG).

\section{Pengaruh Kurs terhadap Indeks Harga Saham Gabungan}

Berdasarkan hasil analisis membuktikan kurs berpengaruh negative dan significant atas Indeks Harga Saham Gabungan (IHSG) tahun 2016-2019. IHSG akan melemah saat nilai tukar rupiah terdepresiasi. Bagi investor sendiri, pelemahan ini menginformasikan bahwa kondisi fundamental perekonomian Indonesia dalam keadaan buruk atau lemah. Saat prospek perekonomian buruk, maka penanam modal mengarah menjual saham-sahamnya, hal tersebut digunakan agar bisa menghindari efek yang didapat. Aktivitas jual saham tersebut akan mendukung lemahnya IHSG. Hasil dari penelitian ini memperkuat penelitian yang dilakukan oleh Witjaksono (2010), Gumilang (2014), dan Husnul (2017) di mana Kurs Rupiah memiliki pengaruh yang negatif terhadap IHSG.

Implikasi teoritis selaras dengan Signalling Theory yang menyatakan kurs memiliki pengaruh terhadap Indeks Harga Saham Gabungan (IHSG). Berubahnya nilai tukar bisa memberikan pengaruh pada pergerakan dalam harga saham dan akan menimbulkan pengaruh dalam investasi di pasar modal. Bagi investor sendiri, pelemahan ini menginformasikan bahwa kondisi fundamental perekonomian Indonesia dalam keadaan buruk atau lemah. Investor diharapkan mampu melihat sinyal ini, sehingga investor dapat memutuskan menjual atau membeli saham dan bisa menghindari efek yang didapat. Implikasi praktisnya adalah sebaiknya kurs dijadkan investor sebagai acuan ketika ingin berinvestasi saham, karena fluktuasi yang terjadi pada kurs dapat memengaruhi Indeks Harga Saham Gabungan (IHSG).

\section{Pengaruh Inflasi terhadap Indeks Harga Saham Gabungan}

Berdasarkan hasil analisis membuktikan bahwa inflasi tidak mempunyai pengaruh significant atas Indeks Harga Saham Gabungan (IHSG) tahun 2016-2019. Dilihat dari data inflasi dalam statistik deskriptif, rata-rata tingkat inflasi pada tahun penelitian yaitu ,000358. Hal ini menunjukkan bahwa tingkat inflasi berada dibawah 10 persen, sehingga pasar masih dapat menerima terjadinya inflasi tersebut. Tetapi jika tingkat inflasi berada diatas 10 persen, maka bursa efek akan terganggu. Jika inflasi diketahui berada diatas angka 10 persen maka BI menaikan BI Rate yang akan menyebabkan penanam modal mengarah mengalihkan modalnya pada sektor perbankan. Selain itu, nilai suku bunga SBI yang tinggi akan mengganggu sektor riil. Penelitian ini sesuai dengan Jayanti (2014) dan Amin (2012) Inflasi tidak berpengaruh terhadap IHSG.

Implikasi teoritis ini tidak selaras dengan Signalling Theory yang menyatakan bahwa inflasi berpengaruh kepada Indeks Harga Saham Gabungan (IHSG), sehingga dapat ditarik kesimpulan bahawa informasi naik dan turunnya inflasi tidak terlalu diperhatikan oleh penanam modal. Penanam modal cenderung mengamati informasi selain inflasi. Implikasi praktis dalam penelitian ini ialah 
sebaiknya investor tidak menjadikan inflasi sebagai acuan atau pertimbangan dalam pengambilan keputusan ketika ingin berinvestasi saham di pasar modal Indonesia.

\section{Pengaruh Harga Minyak Dunia terhadap Indeks Harga Saham Gabungan}

Berdasarkan hasil analisis membuktikan harga minyak dunia tidak mempunyai pengaruh significant atas Indeks Harga Saham Gabungan (IHSG) tahun 2016-2019. Pergerakan harga minyak hanya berpengaruh pada harga saham perusahaan di sektor tertentu saja, contohnya sector energy dan pertambangan energy dan tidak berpengaruh significant atas harga saham sektor lainnya yang tercermin dalam IHSG. Penelitan ini memperkuat penelitian yang dilakukan oleh Sartika (2017) dan Tjandrasa (2016) Harga Minyak Dunia tidak berpengaruh terhadap IHSG.

Implikasi teoritis ini tidak selaras dengan contagion effect theory yang menyatakan bahwa terdapat pengaruh eksternal yang dapat memengaruhi perkembangan Indeks Harga Saham Gabungan (IHSG). Harapan dari penelitian ini ialah dapat menjadi sumbangsih untuk hasil penelitian yang menyatakan bahwa harga minyak dunia tidak bepengaruh terhadap Indeks Harga Saham Gabungan (IHSG). Implikasi praktis ini ialah penanam modal tidak perlu menjadikan harga minyak dunia sebagai acuan atau pertimbangan dalam melakukan investasi saham, karena naik dan turunnya harga minyak dunia tidak berpengaruh kepada Indeks Harga Saham Gabungan (IHSG).

\section{Pengaruh Harga Emas Dunia terhadap Indeks Harga Saham Gabungan}

Berdasarkan hasil analisis membuktikan harga emas dunia tidak mempunyai pengaruh significant atas Indeks Harga Saham Gabungan (IHSG) tahun 2016-2019. Hal itu bisa dilihat pada tahun 2016, 2017, 2018, dan 2019, Harga Emas Dunia mengalami peningkatan dan penurunan. Akan tetapi, IHSG mengalami peningkatan secara terus menerus. Harga Emas Dunia tidak berpengaruh atas pergerakan IHSG disebabkan emas ialah salah satu alternatif investasi. Sebagai opsi investasi emas masih di nilai oleh investor tidak memberikan return yang lebih besar dibandingkan dengan saham. Beberapa investor lebih memutuskan melakukan investasi pada saham yang memiliki high risk dengan return yang juga tinggi. Sehingga walaupun pergerakan harga emas mengalami peningkatan atau penurunan tidak akan memengaruhi pergerakan IHSG, karena keputusan investasi tergantung pada investor dan masih ada opsi investasi lain yang diprediksi bisa memberi keuntungan yang lebih tinggi. Penelitan ini memperkuat penelitian yang dilakukan oleh Sartika (2017) dan Tjandrasa (2016) Harga Emas Dunia tidak berpengaruh terhadap IHSG.

Implikasi teoritis ini tidak selaras dengan contagion effect theory yang menyatakan bahwa terdapat pengaruh eksternal yang dapat memengaruhi perkembangan Indeks Harga Saham Gabungan (IHSG). Harapan dari penelitian ini ialah dapat menjadi sumbangsih untuk hasil penelitian yang menyatakan bahwa harga emas dunia tidak bepengaruh terhadap Indeks Harga Saham Gabungan (IHSG). Implikasi praktis ini ialah penanam modal tidak perlu menjadikan harga emas dunia sebagai acuan atau pertimbangan dalam melakukan investasi saham, karena naik dan turunnya harga emas dunia tidak berpengaruh kepada Indeks Harga Saham Gabungan (IHSG).

\section{KESIMPULAN}

Penelitian ini dilakukan dengan tujuan untuk menganalisis pengaruh BI Rate, kurs, inflasi, harga minyak dunia, dan harga emas dunia atas Indeks Harga Saham Gabungan periode 2016-2019. Alat analisis yang dipakai adalah analisis regresi berganda, maka diperoleh: Hasil dari uji simultan variabel mendapatkan bahwa BI Rate, kurs, inflasi, harga minyak dunia, dan harga emas dunia mempunyai pengaruh secara bersama-sama atas Indeks Harga Saham Gabungan. Pengujian secara individu mendapatkan bahwa terdapat empat variabel yang tidak memiliki pengaruh atas Indeks Harga Saham Gabungan yaitu BI Rate, inflasi, harga minyak dunia, dan harga emas dunia. Sementara itu, variabel kurs berpengaruh negatif atas Indeks Harga Saham Gabungan tahun 2016-2019. 
Ringga Samsurufika Anggriana \& R.A. Sista Paramita. Analisis Pengaruh BI Rate, Kurs, Inflasi, Harga Minyak, dan Harga Emas Dunia terhadap Indeks Harga Saham Gabungan Periode 2016-2019

Terdapat beberapa keterbatasan yang ditemukan pada penelitian ini, di antaranya ialah hasil yang didapatkan kurang jelas yang disebabkan karena terlalu singkatnya periode yang digunakan (4 tahun). Kedua penelitian ini hanya melihat dari faktor ekonomi makro saja.

Bagi investor perlu memperhatikan Indeks Harga Saham Gabungan (IHSG), Kurs sebelum melakukan investasi di pasar modal. Hal ini harus dilakukan karena hasil analisis membuktikan bahwa variabel kurs tersebut signifikan memengaruhi IHSG. Dengan demikan investor akan dapat menghindari kerugian akibat jatuhnya IHSG yang berpengaruh pada jatuhnya harga saham apabila Kurs naik. Bagi penelitian selanjutnya dapat digunakan data harian sehingga mendapatkan hasil penelitian yang lebih akurat. Selain itu, penelitian selanjutnya hendaknya dapat menyempurnakan lagi dengan menambah faktor-faktor makro ekonomi seperti PDB Rustyaningsih \& Purwohandoko (2018), LIBOR Tesa (2012), Indeks Nikkei 225 Widodo (2018) sehingga mampu mendapatkan gambaran yang lebih lengkap mengenai kondisi pasar modal di Indonesia.

\section{DAFTAR PUSTAKA}

Amin, M. Z. (2012). Pengaruh Tingkat Suku Buanga SBI, Nilai Kurs Dollar, Dan Indeks Dow Jones Terhadap Pergerakkan Indeks Harga Saham Gabungan Di Bei. Jurnal Ekonomi, 1-17.

Bank Indonesia. 2019. Pengenalan Inflasi - Bank Sentral Republik Indonesia. (https://www.bi.go.id/id/moneter/inflasi/pengenalan/Contents/Default.aspx. Diakses pada 1 Desember 2019).

Bank Indonesia. 2019. Penjelasan Kurs. (https://www.bi.go.id/id/moneter/informasikurs/Contents/Default.aspx. Diakses pada 28 November 2019).

Chabachib, H. M., \& Agung, A. (2011). Analisis Pengaruh Fundamental Makro dan Indeks Harga Global terhadap IHSG. Jurnal Manajemen, Fakultas Ekonomika Dan Bisnis, 5(17), 63-72.

Fatihudin, D., \& Firmansyah, M. A. (2018). The Effect of Macro Economics on Indeks Harga Saham Gabungan (IHSG) in Indonesia Stock Exchange (IDX) Period 2007-2016. International Journal of Innovative Research and Development, 7(11). https://doi.org/10.24940/ijird/2018/v7/i11/nov18028

Gumilang, R. C., Hidayat, R. R., \& Endang NP, M. G. (2014). Pengaruh Variabel Makro Ekonomi, Harga Emas Dan Harga Minyak Dunia Terhadap Indeks Harga Saham Gabungan (Studi pada Bursa Efek Indonesia Periode 2009-2013). Jurnal Administrasi Bisnis S1 Universitas Brawijaya, 14(2), 1-9.

Handiani, S. (2014). Pengaruh Harga Emas Dunia, Harga Minyak Dunia dan Nilai Tukar Dolar Amerika/Rupiah Terhadap Indeks Harga Saham Gabungan Pada Periode 2008-2013. E-Journal Graduate Unpar, 1(1), 85-93. Retrieved from http://journal.unpar.ac.id/index.php/unpargraduate/article/view/552

Harsono, A. R., \& Wonokinasih, S. (2018). Pengaruh Inflasi, Suku Bunga, Dan Nilai Tukar Rupiah Terhadap INdeks Harga Saham Gabungan (Studi pada Bursa Efek Indonesia Periode 20092013 ). Jurnal Administrasi Bisnis, 60(2), 102-110.

Husnul, H. M., Hidayat, R. R., \& Sulasmiyati, S. (2017). Analisis Pengaruh Inflasi, Kurs (IDR/USD), Produk Domestik Bruto dan Harga Emas Dunia Terhadap Indeks Harga Saham Gabungan. Jurnal Administrasi Bisnis (JAB), 53(1), 66-74.

Idx.co.id. 2019. PT Bursa Efek Indonesia. (https://www.idx.co.id/produk/indeks/. Diakses pada 8 Desember 2019). 
Indonesia.com, C. 2018. Kinerja IHSG 2018, Terburuk dalam 3 Tahun. (https://www.cnbcindonesia.com/market/20181231120250-17-48509/kinerja-ihsg-2018terburuk-dalam-3-tahun. Diakses pada 9 Februari 2020).

Indonesia.com, C. 2019. Hari Terakhir Bursa 2019, Seberapa Hebat IHSG di Asia?. (https://www.cnbcindonesia.com/market/20191230133145-17-126441/hari-terakhir-bursa2019-seberapa-hebat-ihsg-di-asia. Diakses pada 9 Februari 2020).

Jayanti, Y. (2014). Pengaruh Tingkat Inflasi, Tingkat Suku Bunga Sbi, Nilai Tukar Rupiah, Indeks Dow Jones, Dan Indeks Klse Terhadap Indeks Harga Saham Gabungan (IHSG) Studi Pada Bursa Efek Indonesia Periode Januari 2010 â Desember 2013. Jurnal Administrasi Bisnis, $11(1)$.

Kontan.co.id, I. 2017. Analis: Kenaikan IHSG 2017 di atas ekspektasi. (https://investasi.kontan.co.id/news/analis-kenaikan-ihsg-2017-di-atas-ekspektasi. Diakses pada 9 Februari 2020).

Krisna, A. A. G. A., \& Wirawati, N. G. P. (2013). Pengaruh Inflasi, Nilai Tukar Rupiah, Suku Bunga Sbi Pada Indeks Harga Saham Gabungan Di BEI. E-Jurnal Akuntansi Universitas Udayana, $3(2), 421-435$.

Kusumawati, D. A., \& Asandimitra, N. (2017). Impact of Global Index , Gold Price and Macro Economic Variable for Indonesia Composite Index. Journal of Finance and Accounting, 8(2), $53-62$.

Lestari, T., Widarno, B., \& Harimurti, F. (2016). Pengaruh Nilai Tukar Dan Harga Emas Terhadap Indeks Harga Saham Gabungan Di Bursa Efek Indonesia (Pasca Setahun Pelantikan Presiden). Jurnal Akuntansi Dan Sistem Teknologi Informasi, 12(2), 200-207.

Liputan6.com, B. 2016. Tertinggi Kedua di Asia, IHSG Naik 15,32 Persen pada 2016. (https://www.liputan6.com/bisnis/read/2692209/tertinggi-kedua-di-asia-ihsg-naik-1532-persenpada-2016. Diakses pada 9 Februari 2020).

Mahdi, M., \& Kaluge, D. (2009). Pengaruh Tingkat Suku Bunga (Birate) Dan Kurs Dolar As Terhadap Indeks Harga Saham Gabungan (IHSG) Dengan Menggunakan Metode Error Corection Model (Ecm). Jurnal Ekonomi Pembangunan, 9(2), 308. https://doi.org/10.22219/jep.v8i2.3605

Maulinda, T. (2018). Pengaruh Harga Minyak Dunia, Nilai Tukar, Inflasi, Suku Bunga SBI, Indeks Dow Jones, dan Indeks Nikkei 225 terhadap Indeks Sektor Pertambangan yang Terdaftar Di Bursa Efek Indonesia (BEI) Periode 2011-2017. Jurnal Ilmu Manajemen (JIM), 6(3), 314-322.

Maulinda, T. Sh. (2018). Pengaruh Harga Minyak Dunia, Nilai Tukar, Inflasi, Suku Bunga SBI, Indeks Dow Jones, Dan Indeks Nikkei 225 Terhadap Ineks Sektor Pertambangan di Bursa Efeke Indonesia (BEI) Periode 2011-2017. Surabaya.

Nofiatin, I. (2013). Jumlah Uang Beredar, dan Indeks Harga Saham Gabungan ( IHSG ) Periode 2005 - 2011. Jurnal Aplikasi Manajemen, 11(2), 215-222.

Prawirosaputro, B., \& Hapsari, Y. D. (2017). The Effects Of Rupiah Currency, World Oil Prices, And World Gold Price On Composited Stock Price Index (IHSG) In 2016. Jurnal Manajemen, 14(2), 144-151.

Puspitasari, A., Siregar, H., \& Andati, T. (2015). Analisis Integrasi Bursa Saham ASEAN 5 (Analysis of Stock Exchange Integration of ASEAN 5). Jurnal Ekonomi Dan Kebijakan Pembangunan, 
Ringga Samsurufika Anggriana \& R.A. Sista Paramita. Analisis Pengaruh BI Rate, Kurs, Inflasi, Harga Minyak, dan Harga Emas Dunia terhadap Indeks Harga Saham Gabungan Periode 2016-2019

4(2), 187-206.

Robiyanto, R. (2018). the Effect of Gold Price Changes, Usd/Idr Exchange Rate Changes and Bank Indonesia (Bi) Rate on Jakarta Composite Index (Jci)'S Return and Jakarta Islamic Index (Jii)'S Return. Jurnal Manajemen Dan Kewirausahaan, $20(1), \quad 45$. https://doi.org/10.9744/jmk.20.1.45-52

Rochman, A. (2018). Determinan Indeks Harga Saham Gabungan (IHSG) Di Bursa Efek Indonesia. Future: Jurnal Manajemen Dan Akuntansi, 5(2), 119-131.

Rustyaningsih, D., \& Purwohandoko. (2018). Pengaruh Pdb, Inflasi, Nilai Tukar, Harga Minyak Dunia, Harga Emas Dunia Dan Indeks Nikkei 225 Terhadap Indeks Sektor Pertambangan Periode 2011-2016. Jurnal Ilmu Manajemen (JIM), 6(4), 609-619.

Sa'adah, U., \& Suhadak. (2019). Pengaruh Makroekonomi Terhadap Kinerja Indeks Harga Saham Gabungan ( IHSG ) Dan Government Bonds ( Studi pada Negara Indonesia Tahun 2015-2017 ). 73(1), 151-159.

Sartika, U. (2017). Dunia Dan Harga Emas Dunia Terhadap IHSG Dan JII Di Bursa. Jurnal Manajemen Dan Akuntansi, 2(2), 285-294.

Sudarsana, N. M. A. D., \& Candraningrat, I. R. (2014). Pengaruh Suku Bunga SBI, Nilai Tukar, Inflasi Dan Indeks Dow Jones Terhadap Indeks Harga Saham Gabungan Di BEI. The Biochemical Journal, 125(4), 3291-3308. https://doi.org/10.1042/bj1250112Pb

Tandelilin, E. (2010). Portofolio dan Investasi Teori dan Aplikasi (1st ed.). Yogyakarta: Kanisius.

Tempo.com, B. (2016). OJK: IHSG Tumbuh 15,45 Persen Sepanjang 2016. (https://bisnis.tempo.co/read/831344/ojk-ihsg-tumbuh-1545-persen-sepanjang-2016. Diakses pada 9 Februari 2020).

Tesa, S. (2012). Pengaruh Suku Bunga Internasional (Libor), Nilai Tukar Rupiah/Us\$ Dan Inflasi Terhadap Indeks Harga Saham Gabungan Di Bursa Efek Indonesia Tahun 2000-2010. Economics Development Analysis Journal, 1(2). https://doi.org/10.15294/edaj.v1i2.487

Tirto.id. 2019. Tahun Berat Pasar Modal: IHSG Cuma Tumbuh 1,7\% Sepanjang 2019 - Tirto.ID. (https://tirto.id/tahun-berat-pasar-modal-ihsg-cuma-tumbuh-17-sepanjang-2019-epSK. Diakses pada 9 Februari 2020).

Trihadmini, N. (2011). Contagion dan spillover effect pasar keuangan global sebagai early warning system. Finance and Banking Journal, 13(1), 47-61.

Utha, M. A. (2015). Analisis Pengaruh Harga Minyak Dunia Dan Harga Emas Dunia Terhadap Indeks Harga Saham Gabungan Di Bursa Efek Indonesia. Jurnal Informasi, Perpajakan, Akuntansi, Dan Keuangan Publik, Vol. 10, p. 19. https://doi.org/10.25105/jipak.v10i1.4544

Widodo, W. (2018). Analisis Pengaruh Indeks Harga Saham Gabungan Regional Asia Terhadap Indeks Harga Saham Gabungan Indonesia. EkBis: Jurnal Ekonomi Dan Bisnis, 1(2), 148. https://doi.org/10.14421/ekbis.2017.1.2.1016

Witjaksono, A. A. (2010). Analisis Pengaruh Tingkat Suku Bunga SBI, Harga Minyak Dunia, Harga Emas Dunia, Kurs Rupiah, Indeks Nikkei 225, dan Indeks Dow Jones terhadap IHSG. Tesis Universitas Diponegoro. Retrieved from http://eprints.undip.ac.id/24025/1/Ardian_Agung_Witjaksono.pdf 